\title{
scripted
}

Volume 15, Issue 2, October 2018

\section{Trade Marks and the Consumer Society}

\author{
Andrew Griffiths* \\ (ㄷ) (1) $(9)$ \\ (C) 2018 Andrew Griffiths \\ Licensed under a Creative Commons Attribution-NonCommercial- \\ NoDerivatives 4.0 International (CC BY-NC-ND 4.0) license
}

DOI: 10.2966/scrip.150218.209

\begin{abstract}
This article considers how trade marks have increased the ability of some firms to attract demand to their products through exploiting the transformation of the nature of consumption associated with the rise of the "consumer society" or "consumerism". This has involved trends such as the rise of advertising and brand-based marketing, a greater emphasis on the presentation, design and other aesthetics of products, the marketing of "novelty" in various forms along with the rapid upgrading of products and the cultivation of brands as focal points for "values, attitudes and lifestyles" ("VALs") marketing. As the legal platform for branding, trade mark law has enabled some firms to engage in these practices and attract demand to their products despite the space that may lie between them and consumers in the age of market globalisation. The paper considers the social value of this contribution and relates it to broader issues of business ethics and social responsibility.
\end{abstract}

\section{Keywords}

Trade marks; brands; consumerism; marketing; waste; social responsibility 
* Professor of Law, Newcastle Law School, Newcastle University, Newcastle-Upon-Tyne, United Kingdom, andrew.griffiths@ncl.ac.uk

This article is based on papers delivered at the annual conference of the Society of Legal Scholars in September 2016 and at the annual conference of the Socio-Legal Studies Association in April 2017. I am grateful to participants at both conferences for their feedback. I am also grateful to two anonymous referees for their helpful suggestions and comments. 


\section{Introduction}

Firms can use trade marks as the legal platform for brands to attract demand to products that only they can supply and thereby as a means of adding intangible value to these products. Differentiating products in this way can be a source of significant competitive advantage and can help to insulate them from traditional forms of competition. ${ }^{1}$ The growth of the "consumer society" (also known as "consumerism") in the twentieth century has increased the scope that some firms have to differentiate their products and has enabled them to add much greater intangible value and achieve a much greater competitive advantage. Consumerism concerns the pursuit of consumption for reasons other than satisfying physical and material needs. ${ }^{2}$ It involves consumers attaching substantial value to those features of products that individualise them and differentiate them from others on the market. With this trend, consumers have come to value product differentiation for its own sake, ${ }^{3}$ to seek novelty of various kinds in the objects of their consumption and to look to consumption as a means of self-expression, self-realisation or satisfying other emotional desires. ${ }^{4}$ As well

1 Edward Hastings Chamberlin, The Theory of Monopolistic Competition (6 $6^{\text {th }}$ ed) (Oxford: OUP, 1949) pp. 56-57; Edward Hastings Chamberlin, "Product Heterogeneity and Public Policy" (1950) 40 American Economic Review 85-92, p. 86; Ioannis Lianos, "Brands, Product Differentiation and EU Competition Law" in Deven Desai, Ioannis Lianos and Spencer Weber Waller (eds) Brands, Competition Law and IP (Cambridge: CUP, 2015) 146-178, pp. 148152.

2 See for example Colin Campbell, The Romantic Ethic and the Spirit of Modern Consumerism (Oxford: Basil Blackwell, 1987); Avner Offer, The Challenge of Affluence: Self-Control and WellBeing in the United States and Britain since 1950 (OUP, 2006) pp. 278-286; Zygmunt Bauman, Consuming Life (Polity Press, 2007) pp. 25-51.

3 Barton Beebe, "Search and Persuasion in Trademark Law" (2005) 103 Michigan Law Review 2020-2072; Giovanni Battista Ramello, "What's in a Sign? Trademark Law and Economic Theory" (2006) 20 Journal of Economic Surveys 547-565.

4 This has also been expressed as satisfying "non-functional" demand: Harvey Leibenstein, "Bandwagon, Snob, and Veblen Effects in the Theory of Consumers' Demand" (1950) 64 Quarterly Journal of Economics 183-207; Lianos, supra n. 1, p. 157. 
as affecting patterns of demand, consumerism has created new opportunities for firms supplying objects of consumption to increase profits and build up market power. It has encouraged firms to customise and differentiate their products not only in terms of their material quality, but also in terms of their features, design and aesthetics, and of intangible characteristics based on their associations with a particular image or particular set of values. ${ }^{5}$

The growth of consumerism has accompanied the globalisation of the economy, with the emergence of globally-recognised brands as focal points for demand along with a much greater tendency for brand owners to outsource supply into global supply chains. ${ }^{6}$ Trade mark law has facilitated and encouraged these developments through the scope that it gives firms not only to engage in marketing (the attraction of demand) as a distinct activity, ${ }^{7}$ but also to separate the activity of marketing from that of producing the supply needed to meet the demand so attracted. Trade marks have enabled firms to engage in marketing across the space that has opened up between producers and consumers and consumerism has created new opportunities for firms operating within this space. ${ }^{8}$

5 David Alan Garvin, "Competing on the Eight Dimensions of Quality" (1987) 65 Harvard Business Review 101-109.

6 Robert Feenstra, "Integration of Trade and Disintegration of Production in the Global Economy" (1998) 12 Journal of Economic Perspectives 31-50; Gary Gereffi, John Humphrey and Timothy Sturgeon, "The Governance of Global Value Chains" (2005) 12 Review of International Political Economy 78-104, pp. 79-80.

7 On the importance of brand-based marketing to the development of firms, see Mira Wilkins, "The Neglected Intangible Asset: The Influence of the Trade Mark on the Rise of the Modern Corporation" (1992) 34 Business History 66-95; Roy Church and Andrew Godley, "The Emergence of Modern Marketing: International Dimensions" (2003) 45 Business History 1-5; Teresa da Silva Lopes and Mark Casson, "Entrepreneurship and the Development of Global Brands" (2007) 81 Business History Review 651-680.

8 Graeme Austin, "Trademarks and the Burdened Imagination" (2004) 69 Brooklyn Law Review 827-922, p. 843 and pp. 851-852; Bauman, Consuming Life, supra n. 2, p. 26. 
One consequence of consumerism has been a much more rapid pace of consumption, with products becoming obsolescent more quickly. In part, this reflects a greater desire for consuming novelty in various forms in addition to consumption for its own sake. ${ }^{9}$ Consumers attach greater value to products being innovatory or "state-of-the-art" or "on-trend" than to some traditional notions of quality such as durability. This trend can be seen in the section of the garment industry that has developed the "fast fashion" business model and its products that respond to consumers' apparent demand for "new and now". ${ }^{10}$ The overall fashion industry has been valued at over $\$ 1$ trillion and has been ranked as the second largest global economic activity for "intensity of trade" ${ }^{11}$

Consumerism, like fashion trends more broadly, tends to be presented as a transformation in demand in contrast to the transformations in products, production and other aspects of supply that are the traditional focus of interest in innovation. ${ }^{12}$ However, it has at least a consequential effect on supply and on the organisation of the production of that supply. Many firms that have been able to exploit consumerism effectively have also transformed themselves in the process. ${ }^{13}$ Instead of producing the supply to meet the demand that they attract, they have outsourced production and become co-ordinators and orchestrators of supply-provision. It is in relation to the co-ordination of demand-attraction with

9 Colin Campbell, "The Curse of the New: How the Accelerating Pursuit of the New is Driving Hyper-Consumption" in Karin Ekström (ed) Waste Management and Sustainable Consumption (Routledge, 2015) 29-51.

10 Ian Taplin, "Who is to Blame? A Re-examination of Fast Fashion after the 2013 Factory Disaster in Bangladesh" (2014) 10 Critical Perspectives on International Business 72-83, p. 78, citing Robin Lewis and Michael Dart, The New Rules of Retail (Palgrave, 2010) p. 57.

11 Frances Corner, Why Fashion Matters (London: Thames \& Hudson, 2014) p. 71.

12 Dwight Robinson, "The Importance of Fashions in Taste to Business History: An Introductory Essay" (1963) 37 Business History Review 5-36, pp. 7-8.

13 Julie Froud, Adam Leaver and Karel Williams, "New Actors in a Financialised Economy and the Remaking of Capitalism" (2007) 12 New Political Economy 339-347; David Weil, The Fissured Workplace: Why Work Became So Bad for So Many and What Can Be Done to Improve It (Cambridge, Mass.: Harvard University Press, 2014) pp. 7-27. 
supply-provision that trade marks and the brands they signify perform their crucial role. Moreover, these firms are not passive players, simply responding to exogenous changes in demand, but active orchestrators that have sought to shape and influence patterns of demand as well as to take advantage of changes in these patterns in order to increase their profits and their power. ${ }^{14}$ Trade marks and the brands they signify have enabled firms to do all these things through engaging in marketing.

This article will proceed as follows: section 2 will consider the nature of consumerism; section 3 will explain how trade marks as the signifiers of brands along with the law that protects them have facilitated and encouraged the growth of consumerism; section 4 will look at the social impact and cost of consumerism and some issues concerning social responsibility; and section 5 will draw some conclusions.

\section{Consumerism}

Zygmunt Bauman related the advent of "consumerism" to a transformation that occurred in the nature of society "when consumption [took] over that linchpin role which was played by work in the society of producers" ${ }^{15}$ He also portrayed it as one of the consequences that followed the opening up of "an extendable space ... between the act of production and the act of consumption" such that "each of the two acts acquired growing autonomy from the other - so that they could be regulated, patterned and operated by mutually independent institutions". ${ }^{16}$ He argued that "history could be written in terms of the ingenious

14 John Parkinson, Corporate Power and Responsibility (Oxford: The Clarendon Press, 1993) pp. 13-15; Wolfgang Streeck, "Citizens as Consumers: Considerations on the New Politics of Consumption" (2012) 76 New Left Review 27-47.

15 Bauman, Consuming Life, supra n. 2, p. 28.

16 Ibid., p. 26. 
ways in which that space was colonized and administered". ${ }^{17}$ Trade marks and the brands they signify are an important mechanism that firms have been able to use to reach and compete across this space in order to attract demand from consumers to specific products that only they can supply and to organise the supply to meet that demand. Moreover, this mechanism has led to a further extension of this space through enabling some firms both (on the one hand) to communicate with and solicit demand for their products from consumers even when they do not deal with them directly and (on the other hand) to outsource the production of their products into what may be complex and extended supply chains. ${ }^{18}$ Various marketing practices and various organisational structures that rely upon trade marks as their legal platform can be analysed as ways in which firms have sought to colonise this space and take advantage of the various opportunities that its opening up has presented. The growth of consumerism can be viewed as one of these opportunities and one which many firms have been able to anticipate and respond to and have aimed at shaping and influencing.

The term "consumerism" (and variants such as "the consumer society" or "consumer capitalism") can also be used in a broad sense to refer to a change in the nature and social significance of the act of consumption. ${ }^{19}$ The consumption of goods and services has progressed from something primarily concerned with survival or meeting specific material needs into something that has become an important activity in its own right and even a major purpose of life. ${ }^{20}$ As consumers, people have come to rely on consumption as a means of satisfying

17 Ibid.

18 David Brennan, "The Trade Mark and the Firm" [2006] IPQ 283-290; Andrew Griffiths, "Trade Mark Monopolies in the Digital Age" [2016] IPQ 123-151.

19 Supran. 2.

20 See generally Eric Arnould, "Consumer Culture Theory (CCT): Twenty Years of Research" (2005) 31 Journal of Consumer Research 868-882. 
various emotional, psychological and social desires. This has been linked to a trend that has tended to arise as societies become more prosperous, with consumers becoming more interested in satisfying various "higher-order" desires such as those for self-expression, self-realisation and experiencing a sense of community. ${ }^{21}$ This has also led to more prosperous consumers seeking to signal their prosperity and social status through so-called "conspicuous consumption". ${ }^{22}$

The growth of consumerism has had both political and economic significance. $^{23}$ Its political significance can be related to the observation that Bauman made, namely that the role of individuals as consumers has come to challenge or displace their other roles in society and that consumption has become an important means of social interaction and a source of identity. ${ }^{24}$ Whilst the political significance of consumerism is relevant to its social value, this article will focus on its economic significance since this is where trade marks have

21 This view of how human desires progress is drawn from the psychology of Abraham Maslow: Joseph Sirgy, "A Quality-of-Life Theory drawn from Maslow's Developmental Perspective" (1986) 45 The American Journal of Economics and Sociology 329-342. David Aaker and Erich Joachimsthaler, Brand Leadership: The Next Level of the Brand Revolution (New York: The Free Press, 2000) pp. 48-49; Celia Lury, Brands: The Logos of the Global Economy (London: Routledge, 2004) pp. 24 and 34.

22 Leibenstein, supra n. 4; Joseph Monsen and Anthony Downs, "Public Goods and Private Status" (1971) 23 The Public Interest 64-77; Weng Marc Lim, Ding Hooi Ting, Pei Theng Khoo, Wei Yi Wong, "Understanding Consumer Values and Socialization - A Case of Luxury Products" (2012) 7 Management E Marketing: Challenges for the Knowledge Society 209-220. The idea of "conspicuous consumption is associated with Thorstein Veblen, in particular Thorstein Veblen, The Theory of the Leisure Class: An Economic Study of Institutions (New York: Macmillan, 1899). However, the conspicuous consumption that concerned Veblen was directed at more durable products than the modish and ephemeral products associated with consumerism: Bauman, Consuming Life, supra n. 2, pp. 30-31.

23 See, for example, Richard Sennett, The Culture of the New Capitalism (New Haven: Yale University Press, 2006) pp. 157-177; Streeck, supra n. 14; Ed Howker and Shiv Malik, Jilted Generation: How Britain has Bankrupted its Youth (2 ${ }^{\text {nd }}$ ed) (London: Icon Books, 2013) pp. 204212.

24 Streeck, supra n. 14, discussing Monsen and Downs, supra n. 22. 
performed an essential role through providing a legal platform for branding and brand-based marketing.

Consumerism has increased the opportunities for profit for firms that are well-placed to engage in the marketing of products along with other higher value activities such as product design and product development. ${ }^{25}$ It has increased the importance to these firms of marketing as a distinct focus of investment and effort through increasing the ways in which this activity can add substantial intangible value to products. As section 3 will show, trade marks and the brands they signify are an essential resource for firms that wish to engage in marketing and to compete through various forms of product differentiation, including differentiation based on emotional impact and other intangible content. Such firms need a reliable mechanism for differentiating their products in a way that is exclusive to them and under their control and then for engaging in communication about these products and providing the information and reassurance that consumers may need concerning them and their social significance.

The growth of consumerism can be seen in a number of trends relating to marketing that have occurred since the industrial revolution in consumer goods that took place in the late nineteenth century, which coincided with the introduction of the modern trade mark system. These trends include the rise of advertising and brand-based marketing as distinct activities; ${ }^{26}$ the emergence of

25 Peter Gibbon, Jennifer Bair and Stefano Ponte, "Governing Global Value Chains: An Introduction" (2008) 37 Economy and Society 315-338, pp. 317-319; Stefano Ponte and Timothy Sturgeon, "Explaining Governance in Global Value Chains: A Modular Theory-Building Effort" (2014) 21 Review of International Political Economy 195-223, pp. 201-202.

26 Roy Church and Christine Clark, "Product Development of Branded, Packaged Household Goods in Britain, 1870-1914: Colman's, Reckitt's and Lever's" (2001) 2 Enterprise and Society 503-542; Stefan Schwarzkopf, "Turning Trade Marks into Brands: How Advertising Agencies Practiced and Conceptualized Branding, 1900-1930" in Teresa da Silva Lopes and Paul Duguid (eds) Trademarks, Brands and Competitiveness (London: Routledge, 2013) 165-193. 
brands aimed at associating products with fashion and glamour; ${ }^{27}$ and Louis Cheskin's development of marketing techniques that focus on the design, appearance and presentation of products to consumers such as "sensation transference" ${ }^{\prime 28}$ Moreover, since the middle of the twentieth century, many kinds of products have been marketed specifically to appeal to the "values, attitudes and lifestyles" of consumers and, in some cases, through cultivating mythologies around brands. ${ }^{29}$ Developments in communication and technology in the later twentieth century along with market globalisation have further increased the scope for marketing products. ${ }^{30}$ Consumer markets have become much broader and potentially global in scale. Consumerism in this context may lead some firms to aim their products at niche groups of consumers, but even these niche groups do not necessarily have to be constrained by geographical location or proximity.

With the emergence of a much more globalised economy, there has been growing demand for products sold under luxury and heritage brands from consumers in emerging economies. ${ }^{31}$ The appeal of brands of these kinds has led, for example, to the marketing efforts of the "Comite Colbert" of "houses of

27 See, for example, the account of Estée Lauder and "the launch of 'beautiful'" in Nancy Koehn, Brand New: How Entrepreneurs Earned Consumers' Trust from Wedgwood to Dell (Cambridge, Mass.: Harvard Business School Press, 2001) pp. 137-199; Carol Dyhouse, Glamour: Women, History, Feminism (London: Zed Books, 2011).

28 Louis Cheskin, Colors and What They Can Do (London: Liveright Publishing, 1947); Louis Cheskin, How to Predict What People Will Buy (London: Liveright Publishing, 1957).

29 Thomas Drescher, "The Transformation and Evolution of Trademarks: From Signals to Symbols to Myth" (1992) 82 Trademark Reporter 301-340; Douglas Holt and Douglas Cameron, Cultural Strategy: Using Innovative Ideologies to Build Breakthrough Brands (Oxford: OUP, 2010).

30 Feenstra, supra n. 6; Richard Langlois, "Modularity in Technology and Organization" (2002) 49 Journal of Economic Behaviour and Organization 19-37; Suzanne Berger, "Toward a Third Industrial Divide?" in Paul Osterman (ed) Economy in Society: Essays in Honour of Michael J. Piore (Cambridge, Mass.: MIT Press, 2012) 65-88; Ponte and Sturgeon, supra n. 25, pp. 210216.

31 See, for example, Ning Li, Andrew Robson and Nigel Coates, "Luxury Brand Commitment: A Study of Chinese Consumers" (2014) 32 Marketing Intelligence \& Planning 769-793. 
French luxury" directed at these economies; ${ }^{32}$ and is also reflected in the popularity of Clarks Village in Somerset as a destination for tourists from China and South East Asia. ${ }^{33}$ There has also been a greater scope for exploiting the appeal of familiar brands and for broadening and developing their familiarity through marketing practices such as "brand extension" and "brand stretching". ${ }^{34}$ Consumerism has lain behind the practice of sports teams, sports stars and celebrities in general to develop their images and exploit their appeal through various forms of "merchandising". When Advocate General Colomer referred to football clubs as engaging in "an economic activity of the first order", 35 he was referring to their ability to exploit the appeal they had acquired across a range of markets through various forms of merchandising. Consumerism has provided a new business model for football clubs, creative artists and others in which the cultivation of an exploitable image becomes a distinct form of output. ${ }^{36}$

32 See the Comité Colbert's website available at http://www.comitecolbert.com/index.php?lang=en (accessed 8 December 2017).

33 See, for example, Patrick Barkham, "How the Chinese fell in Love with Clarks Shoes" (The Guardian, 9 March 2011) available at http://www.guardian.co.uk/lifeandstyle/2011/mar/09/chinese-love-clarks-shoes (accessed 8 December 2017); "Chinese Visitors surge to grab Brands at Clarks Village Outlet" (Visit Somerset, 15 January 2014) available at http://www.visitsomerset.co.uk/blog/2014/1/15/chinese-visitors-surge-to-grab-brands-atclarks-village-outlet-a95 (accessed 8 December 2017). On Clarks shoes as an object of consumerist desire and a brand with global appeal, see Al Fingers, Clarks in Jamaica (London: One Love Books, 2012).

34 Jay Pil Choi, "Brand Extension as Informational Leverage" (1998) 65 Review of Economic Studies 655-669; Lynne Pepall and Dan Richards, "The Simple Economics of Brand Stretching" (2002) 75 Journal of Business 535-552.

35 "[Leading football clubs] are not mere sporting associations whose aim is the playing of football, but genuine 'emporia' which, with the object of playing professional football, pursue an economic activity of the first order": Arsenal FC plc $v$ Matthew Reed [2002] ETMR 975 (Advocate General's Opinion) [84].

36 On the possibilities and pitfalls of exploiting celebrity in this way, see for example Joe Muggs, "Sorry Perez - You Just Don't Get It" (The Guardian, 8 October 2009) available at https://www.theguardian.com/music/2009/oct/08/perez-hilton-pop-brands (accessed 8 December 2017). 
Another aspect of consumerism is the high value that consumers have come to attach to various forms of product novelty. ${ }^{37}$ In a survey of what he termed "the accelerating pursuit of the new", Colin Campbell identified three forms of novelty that consumers may seek in objects of consumption and related these to three forms of consumption. ${ }^{38}$ First, there are products that are new in the sense of being fresh or "brand new", which are the objects of "replacementdriven consumption of the new" or of consumption for the first time. ${ }^{39}$ Secondly, there are products that are new in the sense that they are a new kind of product, or the latest version, or an improved or innovative version, which are the objects of "innovation-driven consumption of the new". ${ }^{40}$ Thirdly, there are products that are new in the sense that they are novel, newly fashionable or "must-have" (as in " $\mathrm{X}$ is the new $\mathrm{Y}$ "), which are the objects of "fashion-driven consumption of the new". ${ }^{41}$ As Campbell recognised, these three forms of consumption may overlap extensively in practice and a particular product can be new in all three senses. ${ }^{42}$

A good example of products that combined all three forms of novelty and could be the objects of all three forms of consumption were various fashion products featuring classic brand names and logos from the later twentieth century, which became fashionable in 2016. These included Vetements" "DHL T shirt" and Anya Hindmarch's "Boots' boots", which retailed at $£ 185$ and $£ 895$

37 Campbell, supra n. 9, p. 29.

38 Ibid., p. 30. See further Colin Campbell, "The Desire for the New: Its Nature and Social Location as Presented in Theories of Fashion and Modern Consumerism" in Roger Silverman and Eric Hirsch (eds) Consuming Technologies: Media and Information in Domestic Spaces (Routledge, 1992) 48-64.

39 Ibid., pp. 30-36.

$40 \quad$ Ibid., pp. 36-38.

41 Ibid., pp. 38-40.

42 Ibid., pp. 30. 
respectively. ${ }^{43}$ Much of the "value" in these products that enabled them to command such high prices was intangible in nature, reflecting their design, image, the statement that they enabled wearers to make about themselves and their branding. ${ }^{44}$ A consumer buying a Vetements' DHL T shirt in 2016 would have been simultaneously buying a brand new $\mathrm{T}$ shirt, the latest Vetements' $\mathrm{T}$ shirt and a "must-have" fashion product for that year.

Whilst these fashion products incidentally featured classic logos such as those of "DHL" and "Boots", the trade marks that were crucial to attracting demand and adding substantial intangible value to them were the brand names and other signifiers of the firms that marketed them, such as Vetements and Anya Hindmarch. These gave the products the distinctive marketing identities that helped to define them as specific objects of consumption and helped to differentiate them from other products on the market. The exclusivity of the brands to their owners meant that products sold under them had a specific commercial provenance and could benefit from the reputation and other associations of the brands. This was a source of reassurance to consumers on a number of matters such as the likely quality of the products and in particular their fashionable and "must-have" status. ${ }^{45}$ The signifiers of the brands also provided reference points for communication about these products and for seeking and conveying information about them, including reviews,

43 See Lauren Cochrane, "Scam or Subversion? How a DHL T Shirt Became This Year's MustHave" (The Guardian, 20 April 2016) available at https://www.theguardian.com/fashion/2016/apr/19/dhl-t-shirt-vetements-fashion-pariscatwalk (accessed 8 December 2017).

44 The high value of intangible content in clothing can be seen in the proportions in which parties in a value chain share the eventual retail price: Rosemary Westwood, "What does that \$14 shirt really cost?" (Maclean's, 1 May 2013) available at http://www.macleans.ca/economy/business/what-does-that-14-shirt-really-cost/ (accessed 8 December 2017).

45 Brian Hilton, Chong Ju Choi and Stephen Chen, "The Ethics of Counterfeiting in the Fashion Industry: Quality, Credence and Profits Issues" (2004) 55 Journal of Business Ethics 345-354. 
recommendations and endorsements by expert commentators and others on whose judgement consumers were likely to rely. This referential role also assisted in the promotion of the products and their attainment of the status of being fashionable and "must-have" and trade marks enabled consumers to express demand for the specific products in question.

Trade marks as the signifiers and legal anchors of brands can go much further in facilitating consumerist consumption. They give their owners exclusive control along with flexibility and discretion both as to the products that are sold under them and as to the production of these products. The next section will examine these roles in more detail.

\section{How Trade Marks Facilitate Consumerism}

Ownership of a trade mark gives a firm exclusive rights covering two matters. ${ }^{46}$ One is the exclusive right to use the sign to brand and differentiate products of a kind for which it has been registered as a trade mark and turn them into specific objects of demand. The second is the exclusive right to determine which products can be marketed under the trade mark and thus with the benefit of its power to attract demand. ${ }^{47}$ The owner's exclusive right to use a trade mark to attract demand is reinforced by various ancillary rights over the use of the relevant sign and similar signs both for branding products and as reference points in advertising and in other communication. The owner's exclusive control over the supply of branded products is also reinforced by various ancillary rights. These include the absolute right to authorise the first marketing of products under the

46 Griffiths, supra n. 18.

47 Major Bros. v Franklin E Son [1908] 1 KB 712 (HC); Case C-9/93 IHT v Ideal-Standard [1994] ECR I-2789 [37]; Primark v Lollypop Clothing [2001] FSR 637 (HC). 
trade mark in the European Economic Area ("EEA"); ${ }^{48}$ and certain rights over the further marketing of branded goods after their first marketing in the EEA, which protect the trade mark's reputation and power to attract demand. ${ }^{49}$ Moreover, along its exclusive control over supply, the owner has discretion as to how it arranges for the production or procurement of that supply and to vary these arrangements. ${ }^{50}$

The owner's extensive control over the use of its trade mark for demandattraction and over supply-provision, together with its discretion over the organisation of supply have made crucial contributions to the ability of some firms to exploit the opportunities of consumerism. It has meant that the marketing of products can be separated from their production so that each activity can develop according to its own economic logic in terms of scale and scope. The ability to do this has enabled firms that are well-placed to attract demand from consumers to focus their efforts and resources on marketing and other higher value activities and to compete at this level. Leading firms in many industries no longer engage in the "Fordist" mass production of products, ${ }^{51}$ but focus on high value "weightless" activities such as design, product development,

48 Directive 2008/95/EC of the European Parliament and of the Council of 22 October 2008 to approximate laws of the Member States relating to trade marks [2008] OJ L 299/25 (hereinafter 'Directive 2008/95/EC'), art. 7; Trade Marks Act 1994, s. 12. See Case C-355/96 Silhouette v Hartlauer [1998] ECR I-4799; Joined Cases C-414/99-C-416/99 Zino Davidoffv A E G Imports [2001] ECR I-8691.

49 Directive 2008/95/EC, art. 7; Trade Marks Act 1994, s. 12. See Case C-427/93 Bristol-Myers Squibb v Paranova [1996] ECR I-3457; Case C-348/04 Boehringer Ingelheim v Swingward (No. 2) [2007] ECR-3391; Case C-276/05 Wellcome v Paranova [2008] ECR I-10479.

50 The commercial origin that a trade mark guarantees "is not defined by reference to the manufacturer but by reference to the point of control of manufacture": Case C-9/93 IHT $v$ Ideal-Standard [1994] ECR I-2789 [37]. See Brennan, supra n. 18.

51 Robin Murray, "Fordism and Post-Fordism" in Stuart Hall and Martin Jacques, New Times: The Changing Face of Politics in the 1990s (London: Lawrence \& Wishart, 1989) 38-53; Julie Froud, Sukhdev Johal, Adam Leaver and Karel Williams, "Financialization across the Pacific: Manufacturing Cost Ratios, Supply Chains and Power" (2014) 25 Critical Perspectives on Accounting 46-57. 
marketing whilst orchestrating production from fluid and flexible supply chains. ${ }^{52}$ Innovation in technology and communication has increased the scope for outsourcing production into supply chains, enabling much greater flexibility in production arrangements and facilitating more rapid product development. ${ }^{53}$ Consumerism has increased the advantage of outsourcing production in a way that combines low costs with a high degree of flexibility. ${ }^{54}$ The transformation of Clarks Shoes in the 1990s from a large-scale manufacturer of shoes in the United Kingdom to a global marketing firm that orchestrates the manufacture of shoes through a fluctuating global supply network of manufacturers is an example of this. ${ }^{55}$ It can also be seen in the fast fashion industry with its globally-recognised brands and global supply chains. ${ }^{56}$

Whilst the control and discretion that trade mark owners have over supply is important to their capacity to seize and exploit the opportunities of consumerism, their demand-side control makes a much more obvious contribution to this capacity. The foundation of this contribution is the owner's ability to use a trade mark to give products an identity that is distinctive and exclusive. This kind of identity roughly corresponds to the marketing concept of a brand, though a "brand" is not defined in trade mark law and its relationship

52 "What these companies produced primarily were not things ... but images of their brands. Their real work lay not in manufacturing but in marketing. This formula ... has companies competing in a race towards weightlessness": Naomi Klein, No Logo (Flamingo, 2000) p. 4 (emphasis in the original). This trend has been a feature of the financialised form of capitalism that has evolved alongside the market form of globalisation since the 1980s: Julie Froud et al, "Shareholder Value and the Political Economy of Late Capitalism" (2000) 29 Economy and Society 1-12; Froud, Leaver and Williams, supra n. 13.

53 Supra n. 30.

54 Campbell, supra n. 9, pp. 39-40.

55 Supra n. 33.

56 See generally All Party Parliamentary Group on Bangladesh, "After Rana Plaza: A Report into the Readymade Garment Industry in Bangladesh" (2013) ("the APPB Report"), available at

http://www.annemain.com/files/attachments/APPG Bangladesh Garment Industry Report. pdf (accessed 8 December 2017). 
with a trade mark can be nebulous. ${ }^{57}$ Trade marks are both the signifiers and the legal anchors of brands. A firm may use more than one trade mark to signify and anchor a specific brand and may vary the combination or change them, ${ }^{58}$ though consumers must be likely to recognise each signifier on its own as signifying an exclusive connection to one firm for it to be registered as a trade mark. ${ }^{59}$

The legal definition of a trade mark as a sign that identifies and distinguishes products as those "of one undertaking" understates the full potential of brands and their trade mark signifiers as marketing resources. ${ }^{60}$ Firms can use trade marks to differentiate products in other ways as well. Firms can, for example, use trade marks to customise products in terms of their quality and other characteristics and to market different versions of the same kind of product. ${ }^{61}$ Moreover, a brand owner has control over the customisation that its brand reflects, with discretion to vary quality and other characteristics as long as the brand does not become misleading. ${ }^{62}$ Firms can also use trade marks to establish different layers of brands under their control to signify different layers of information about the products they supply. These may range from broader corporate or umbrella brands to narrower product or niche brands. ${ }^{63}$ Their

57 See, for example, Jennifer Davis and Spyros Maniatis, "Trademarks, Brands, and Competition" in Teresa da Silva Lopes and Paul Duguid (eds) supra n. 26, 119-137, pp. 120122; Deven Desai and Spencer Weber Waller, "Brands, Competition, and Antitrust Law" in Deven Desai, Ioannis Lianos and Spencer Weber Waller (eds) supra n. 1, 75-112, pp. 77-83.

58 Starbucks, for example, changed the appearance of its mermaid logo in early 2011: "Starbucks drops its Name and the Word Coffee from its Logo" (BBC News, 6 January 2011) available at http://www.bbc.co.uk/news/business-12125440 (accessed 8 December 2017).

59 Case C-215/14 Société des Produits Nestlé v Cadbury [2015] Bus LR 1034; Société des Produits Nestlé v Cadbury [2017] EWCA Civ 358.

60 Directive 2008/95/EC, art. 2; Trade Marks Act 1994, s. 1(1).

61 Andrew (John) v Kuehnrich (1913) 30 RPC 677(CA).

62 Scandecor Development $v$ Scandecor Marketing [2001] ETMR 800 (HL).

63 On corporate and product brands, see Carol Corrado and Janet Xiaohui Hao, "Brands as Productive Assets: Concepts, Measurement and Global Trends" (2014) WIPO Economic Research Working Paper No. 13, p. 10, available at 
owners have discretion as to how far (if at all) they make the connections between different brands under their control apparent to consumers.

The ability to use branding to customise products and to establish different product brands means that firms can profit from satisfying consumers with differing preferences. ${ }^{64}$ This enables firms to compete more effectively in the dimension of product differentiation, especially with the growth of the tendency associated with consumerism for consumers to attach greater value to differentiation, even superficial differentiation, for its own sake. ${ }^{65}$ The growth of consumerism has also increased the scope for attracting demand to specific brands of products because of their particular intangible content, which may be their only significant difference from other brands. ${ }^{66}$ Trade mark law has done much to facilitate the capacity of brands to add intangible content to products through protecting the kind of image and other associations that can give them this capacity. The Court of Justice of the European Union ("CJEU") has gone so far as to recognise that an image of prestige and luxury can form part of the "actual quality" of marked products. ${ }^{67}$

The foundation of a brand's capacity to add intangible content is its exclusivity since this gives it an institutional character and establishes

http://www.wipo.int/edocs/pubdocs/en/wipo pub econstat wp 13.pdf (accessed 8 December 2017).

64 Silva Lopes and Casson, supra n. 7, p. 655. On the value of product customisation and its different forms, see Joseph Pine II and James Gilmour, The Experience Economy (Cambridge, Mass.: Harvard Business Review Press, 2011) pp. 107-116 and pp. 130-141.

65 Supra nn. 3-4.

66 Gary Becker, Kevin Murphy and Edward Glaeser, "Social Markets and the Escalation of Quality: The World of Veblen Revisited" in Gary Becker and Kevin Murphy (eds) Social Economics: Market Behaviour in a Social Environment (Cambridge, Mass.: The Belknap Press, 2001) 84-104.

67 "[T] he quality of luxury goods ... is not just the result of their material characteristics, but also of the allure and prestigious image which bestows on them an aura of luxury ... [A]n impairment to that aura of luxury is likely to affect the actual quality of those goods": Case C-59/08 Copad v Christian Dior Couture [2009] ECR I-3421[24]-[26]. 
commercial accountability for branded products. It enables the brand to acquire a reputation concerning the branded products, which can be a source of reassurance to consumers and attract demand accordingly. ${ }^{68}$ Moreover, as a cohesive entity with some of the attributes of a humanistic personality, a brand can go further and acquire its own unique history and biography along with an image and other associations. ${ }^{69}$ This can appeal to consumers at the emotional level and help to offset the impersonal nature of artificial legal structures. ${ }^{70}$ The continuity of this personality can turn what would otherwise be an isolated act of consumption into something that can be repeated or a continuing relationship. ${ }^{71}$ A brand's personality can also help to increase the emotional impact of consumption through transforming branded products into sources of self-expression or self-realisation or into symbols of status or of adherence to particular values reflecting the brand's reputation, image and associations. ${ }^{72}$ Trade marks can help to develop the personalities of the brands they signify through their ancillary role as reference points. Their owners can use them in advertising and other promotional activity to cultivate or reinforce images and other associations for their brands. Brands with the capacity to add intangible

68 Benjamin Klein and Keith Leffler, "The Role of Market Forces in Assuring Contractual Performance" (1981) 89 Journal of Political Economy 615-641; William Landes and Richard Posner, "Trademark Law: An Economic Perspective" (1987) 30 Journal of Law and Economics 265-309; Nicholas Economides, "The Economics of Trademarks" (1988) 78 Trademark Reporter 523-539.

69 Jonathan Kahn, "Product Liability and the Politics of Corporate Presence: Identity and Accountability in Macpherson v. Buick" (2001) 35 Loyola of Los Angeles Law Review 3-64, pp. 3041.

70 Roland Marchand, Creating the Corporate Soul: The Rise of Public Relations and Corporate Imagery in American Big Business (Berkeley: University of California Press, 2001) pp. 7-47.

71 "Fifty-seven years later, she still recalled the taste of that Coke on that summer day ... From then on ... she always asked for Coca-Cola.": Constance Hays, Pop: Truth and Power at the Coca-Cola Company (London: Arrow, 2005) pp. 8-9.

72 Barton Beebe, "Intellectual Property Law and the Sumptuary Code" (2010) 123 Harvard Law Review 809-889; Holt and Cameron, Cultural Strategy, supra n. 29. 
content to products can become something much more than a means of product differentiation and sources of guidance and reassurance about product quality and characteristics.

Trade mark law has boosted the potential of brands to attract demand in this way through its calibration of the ancillary rights of their owners. The owner of a trade mark that has acquired a reputation in the minds of consumers is entitled to prohibit third parties who are marketing or supplying products of any kind from using the same or a similar sign in a way that creates a mental "link" with the trade mark (that is bringing the trade mark to the minds of consumers encountering the third party's sign) and as a consequence of this link has one or more of three designated effects on the trade mark. ${ }^{73}$ The designated effects are to damage the trade mark's "distinctive character", to damage its "repute" and to take "unfair advantage" of these without "due cause".

The CJEU has confirmed that this additional protection for certain trade marks goes beyond the traditional boundary of protection, which requires an infringing sign to be likely to confuse consumers about the commercial origin of the third party's products or to create a false impression that there is an economic link of some kind with the trade mark or its owner. ${ }^{74}$ Instead, this additional protection increases the control that the owner has over its trade mark's presence in the minds of consumers and thereby increases its value as a resource for attracting attention and demand. It protects the prominence that the trade mark may enjoy in the minds of consumers and the factors that enable it to attract

73 Directive 2008/95/EC, art. 5(2); Trade Marks Act 1994, s. 10(3). See Case C-375/97 General Motors v Yplon [1999] ECR I-5421; Case C-252/07 Intel v CPM [2008] ECR I-8823 ; Case C-487/07 L'Oréal v Bellure [2009] ECR I-5185; Case C-323/09 Interflora v Marks \& Spencer [2012] Bus LR 1440; Case C-252/12 Specsavers v Asda [2013] Bus LR 1277.

74 Case C- 292/00 Davidoff \& Cie v Gofkid [2003] ECR I-389; Case C-408/01 Adidas-Salomon v Fitnessworld [2003] ECR I-12537. 
demand, which can include an appealing image as well as a good reputation concerning product quality. ${ }^{75}$ It also enables the owner to prevent unfair exploitation of these features of its trade mark's presence. In a controversial judgment, the CJEU ruled that a third party can take unfair advantage of such a presence even where it causes no damage to that presence and there is no likelihood of consumers being misled about commercial origin. ${ }^{76}$ In a similar line of development, the CJEU has ensured that the owner's control over third parties' use of its trade mark as a reference point in their own advertising and promotional activity is sufficient to protect its image and associations as well as its meaning as a trade mark. ${ }^{77}$

As well as facilitating the cultivation of images and associations for the brands they signify through their use as reference points, trade marks can contribute directly to their emotional impact and power to attract demand. A trade mark's distinctiveness and nature as a sign can boost its potential to gain salience in the minds of consumers. ${ }^{78}$ Some signs such as logos or shapes may contribute to the aesthetic impact of a brand. However, trade mark law imposes restrictions on the ability of firms to appropriate such signs for their exclusive use as trade marks. The main overriding condition of registration is that a sign must have distinctive character in the sense that relevant consumers must be likely to perceive it as signifying an exclusive connection to one firm and thus as

75 Case C-337/95 Parfums Christian Dior v Evora [1997] ECR I-6013; Case C-59/08 Copad v Christian Dior Couture [2009] ECR I-3421; Case C-46/10 Viking Gas v Kosan Gas (C-46/10) [2011] ETMR 58 (WL).

76 Case C-487/07 L'Oréal v Bellure [2009] ECR I-5185. See further Dev Gangjee and Robert Burrell, "Because You're Worth It: L'Oréal and the Prohibition on Free Riding" (2010) 73 MLR 282304.

77 Case C-337/95 Parfums Christian Dior v Evora [1997] ECR I-6013; Case C-63/97 BMW v Deenik [1999] ECR I-905; Case C-487/07 L'Oréal v Bellure [2009] ECR I-5185.

78 Andrew Ehrenberg, Neil Barnard and John Scriven, "Differentiation or Salience" (1997) 37 Journal of Advertising Research 7-14; Barton Beebe, "The Semiotic Analysis of Trademark Law" (2004) 51 UCLA Law Review 621-704. 
a trade mark. ${ }^{79}$ This can be a difficult condition for signs not traditionally or typically used as trade marks (such as shapes or colours) to satisfy. ${ }^{80}$

There are further restrictions on the ability to register shapes as trade marks even if consumers may have come to perceive them as trade marks through their use as such. ${ }^{81}$ These include a restriction on shapes that add substantial value for reasons that are not brand-related such as their aesthetic appeal, ${ }^{82}$ though in practice it can be hard to disentangle the inherent allure of a sign from other factors that may give it emotional impact. ${ }^{83}$ These further restrictions are due to be extended to cover product characteristics in general. ${ }^{84}$ However, apart from these restrictions, trade mark law does not preclude firms from registering aesthetically-appealing signs as trade marks once consumers have come to perceive them as such even though their owners may thereby gain an extensive zone of exclusivity..$^{85}$

Trade marks that signify verbally may bring attractive connotations and associations to brands through any alternative meanings or significance they may have and a firm may select a brand name or other trade mark for this reason. Trade mark law places some restrictions on the ability of firms to appropriate

79 Directive 2008/95/EC, art. 3(1)(b); Trade Marks Act 1994, s. 3(1)(b).

80 Case C-299/99 Koninklijke Philips Electronics v Remington [2002] ECR I-5475; Case C-104/01 Libertel Groep v Benelux-Merkenbureau [2003] ECR I-3793; Société des Produits Nestlé v Cadbury [2017] EWCA Civ 358.

81 Directive 2008/95/EC, art. 3(1)(e).

82 Case T-508/08 Bang \& Olufsen v OHIM [2011] ECR II-6975; Case C-205/13 Hauck v Stokke [2014] Bus LR 1284.

83 Case C-371/06 Benetton v G-Star International [2007] ECR I-7709.

84 Directive (EU) 2015/2436 of the European Parliament and of the Council of 16 December 2015 to approximate the laws of the Member States relating to trade marks (Recast) [2015] OJ L 336/1, art. 4(1)(e). Member states are required to implement the Recast Directive by early 2019.

85 As has been argued to be the case with Adidas's "three parallel stripes" trade mark, which can enjoy protection against clothing featuring two parallel strips: Case C-102/07 Adidas v Marca Mode [2008] ECR I-2439. 
words and word-combinations of this kind as trade marks, but these are limited ${ }^{86}$ There are restrictions on the registration of signs that are entirely descriptive or have some other entirely non-origin significance for the relevant kind of products, at least not until they have acquired sufficient familiarity through use as trade marks in practice to displace their alternative significance. ${ }^{87}$ However, these restrictions do not preclude trade marks from having descriptive elements or being suggestive or allusive to the quality or characteristics of the branded products. Cases involving everyday words such as "sky" and "apple" show how firms can gain zones of exclusive control over words with pre-existing meanings through registering them as trade marks. ${ }^{88}$ Trade mark law does provide for applications to register signs as trade marks to be refused for bad faith and this provision can apply where a firm seeks to register a sign that is likely to have significant emotional impact or attract significant demand for some other reason and where the applicant has no good reason to appropriate this appeal for its exclusive use. ${ }^{89}$

A further point relevant to consumerism is that a trade mark can be positioned where consumers would not notice them prior to purchase. ${ }^{90}$ Such trade marks function as a means of subsequent brand authentication, but their invisibility may also add to the allure of products sold under a niche brand to consumers who are seeking the emotional satisfaction of feeling part of a select

86 Jennifer Davis, "The Need to Leave Free for Others to use and the Trade Mark Common" in Jeremy Phillips and Ilanah Simon (eds) Trade Mark Use (Oxford: OUP, 2005) 29-45.

87 Directive 2008/95/EC, art. 3(1)(c) and (d); Trade Marks Act 1994, s. 3(1)(c) and (d). See Case C-191/01 OHIM v Wrigley [2003] ECR I-12447; C-353/03 Société des Produits Nestlé v Mars UK [2005] ECR I-6135.

88 Apple Corps Limited v Apple Computer, Inc. [2006] EWHC 996; B Sky B v Microsoft [2013] EWHC 1826.

89 See, for example, Jules Rimet Cup v The F.A. [2007] EWHC 2376. See further Norma Dawson, "Bad Faith in European Trade Mark Law" [2011] IPQ 229-258.

90 Société des Produits Nestlé v Cadbury [2017] EWCA Civ 358 [51]. See further Peter Prescott, "Trade Marks Invisible at the Point of Sale: Some Corking Cases" [1990] EIPR 241-245. 
community. ${ }^{91}$ Nevertheless, for trade marks used in this way, as with all trade marks that are ancillary contributors to a brand, it is still necessary that relevant consumers should be likely to perceive them on their own as signifying an exclusive connection to one firm even though they are not used on their own in practice. $^{92}$

\section{Some Reflections on Social Cost}

The main aim of this article has been to consider the phenomenon of consumerism and to demonstrate the crucial role that trade marks and the brands they signify have played in enabling and encouraging firms to exploit it. This section will consider the overall social impact of consumerism since this may provide some guidance for evaluating trade mark law's enabling and encouragement of it. There are three broad issues to consider in this respect. The first is how far encouraging the supply of products to satisfy consumerist demand can be viewed as socially beneficial. This relates especially to the use of brands to customise and differentiate products in ways that appeal to consumers (or some of them) at the emotional level. The second issue is the overall social cost of producing this supply in terms of environmental impact and poor working conditions for those engaged in production. The third issue is the extent to which branding may or may not achieve some mitigation of the social costs of consumerism through establishing commercial accountability for branded products that may cover the social costs of their production as well as their quality.

\footnotetext{
91 At the extreme, such trade marks may contribute to the cultish appeal of a "secret" brand, such as that featured in William Gibson, Zero History (London: Viking, 2010).

92 Case C-215/14 Société des Produits Nestlé v Cadbury [2015] Bus LR 1034; Société des Produits Nestlé v Cadbury [2017] EWCA Civ 358.
} 
It is debatable how far satisfying consumerist demand can be viewed as socially beneficial simply because consumers are willing to pay more for products that satisfy it. ${ }^{93}$ It has been argued that demand rooted in emotional desire is quite different in character from demand based on functional need. It cannot be satisfied through an act of consumption in the same way and has a potentially insatiable aspect. As Bauman commented, consumerism "associates happiness not so much with the gratification of needs ... as with an ever rising volume and intensity of desires". ${ }^{94}$ This is especially so in the case of "innovationdriven" consumption and "fashion-driven" consumption, where some consumers are likely to feel a continuing pressure to buy new products, ${ }^{95}$ and also with consumption driven by a desire to demonstrate social position or status. $^{96}$

A firm that is well-placed to attract demand of this character can achieve a significant competitive advantage through satisfying it. It accentuates the anticompetitive effects of brand-based product differentiation. ${ }^{97}$ Branding products turns them into specific objects of consumption that only the brand's owner can supply. This is a source of competitive advantage and consequential strategic power because the demand for such products tends to be much less elastic that if they were readily substitutable. ${ }^{98}$ Consumers would also face significant

93 See, for example, Offer, The Challenge of Affluence, supra n. 2, pp. 103-137; Sennett, The Culture of the New Capitalism, supra n. 23, pp. 136-142.

94 Bauman, Consuming Life, supra n. 2, p. 31 (emphasis in the original). See also Giovanni Battista Ramello and Francesco Silva, "Appropriating Signs and Meaning: The Elusive Economics of Trademark" (2006) 15 Industrial and Corporate Change 937-963, pp. 946-949.

95 Supra nn. 38-41.

96 Supra n. 22.

97 Supra n. 1. See also Davis and Maniatis, supra n. 57.

98 On elasticity, see Peter Newman, "Elasticity" in Steven Durlauf and Lawrence Blume (eds) The New Palgrave Dictionary of Economics (2nd ed) (Basingstoke: Palgrave Macmillan, 2008). 
"switching costs" in selecting an alternative product, 99 especially if they have formed a strong emotional bond with the brand. ${ }^{100}$ Moreover, the owner has the advantage of being able to confer the intangible content that the brand represents onto products at a relatively low marginal cost. The fact that under European trade mark law the owner's exclusive control over supply is only exhausted upon the first marketing of branded goods in the EEA further strengthens this advantage by enabling the owner to engage in territorial price discrimination for branded products. ${ }^{101}$

The debatable social value of consumerism calls into question how far it is possible to justify trade mark law's enabling and encouragement of firms to seek to attract this kind of demand and supply products to satisfy it. This applies in particular to the extension of the exclusive rights of some brand owners to enable them to protect the images and associations of their brands where these increase their power to attract demand. The rationale of trade mark law in the European Union is to promote a system of undistorted competition and the CJEU has ruled that such a system should enable firms to gain and protect a competitive advantage based on the particular quality of their products. ${ }^{102}$ It is far from clear that extending protection beyond what is necessary to ensure the exclusivity of a trade mark and to protect the meaning that it acquires as the signifiers of an exclusive identity is consistent with this rationale. This is

99 On switching costs, see Paul Klemperer, "Markets with Consumer Switching Costs" (1987) 102 Quarterly Journal of Economics 375-394.

100 Supra n. 71.

101 Supra n. 48. On territorial price discrimination, see Keith Maskus, "Economic Perspectives on Exhaustion and Parallel Imports" in Irene Calboli and Edward Lee (eds) Research Handbook on Intellectual Property Exhaustion and Parallel Imports (Cheltenham: Edward Elgar, 2016) 106124, pp. 112-113.

102 Case C-10/89 Cnl Sucal v Hag [1990] ECR I-3711 [13]; Case C-427/93 Bristol-Myers Squibb v Paranova [1996] ECR I-3457[43]; Case C-349/95 Loendersloot (Frits) v Ballantine [1997] ECR I6227 [22]. 
especially so when, even if it is accepted that intangible content should be treated as a form of product "quality", it is contestable as to how far it should be treated as the exclusive property of the brand owner. ${ }^{103}$

As regards social cost, there has been concern about the impact of consumerism on the environment and the waste of resources that consumerism encourages due to its emphasis on novelty and the rapid product obsolescence that results from this. ${ }^{104}$ However, much of the concern about consumerism generally focuses on adverse effects that occur in the supply chains of brand owners. The garment industry, for example, with its fast fashion business model, has been associated with consumer waste and with harmful environmental impacts and infringements of human rights in its supply chains. These environmental impacts prompted Greenpeace to launch its “Detox my Fashion" campaign in 2011 and its associated "Detox Catwalk" rankings. ${ }^{105}$ Poor working conditions and issues concerning human rights have been highlighted in a number of incidents, in particular the Rana Plaza disaster of 2013. ${ }^{106}$

It has been noted how, in order to achieve the low costs and flexibility of production necessary to exploit consumerist demand most effectively and maximise their profits from doing so, many firms outsource production into global supply chains. A further advantage of outsourcing is that it enables brand owners to avoid the risks and costs of production, including responsibility for working conditions and environmental impact. ${ }^{107}$ In effect, the discretion that brand

\footnotetext{
103 Dev Gangjee, "Property in Brands", in Helena Howe and Jonathan Griffiths, Property Concepts in Intellectual Property Law (Cambridge: CUP, 2013) 29-59.

104 See generally Ekström, supra n. 9.

105 See "The Detox Catwalk 2016" available at http://www.greenpeace.org/international/en/campaigns/detox/fashion/detox-catwalk/ (accessed 8 December 2017).

106 See APPB Report, supra n. 56; Andreas Rühmkorf, Corporate Social Responsibility, Private Law and Global Supply Chains (Cheltenham: Edward Elgar, 2015) pp. 147-156.

107 Klein, No Logo, supra n. 52, p. 202; Weil, The Fissured Workplace, supra n. 13.
} 
ownership gives firms concerning the production of the supply of branded products enables them to externalise the risks and responsibilities of production. ${ }^{108}$ Moreover, the competitive advantage that brand owners enjoy due to their exclusive right to confer the brand and its power to attract demand onto products can create competitive pressures within supply chains that exacerbate their adverse effects. ${ }^{109}$

Business models based on attracting consumerist demand along with the ability of firms to brand their products have facilitated a general reorganisation of business activity whereby lead firms outsource some or all of the material production of their products into flexible supply chains and focus their resources on higher value activities relating to demand-attraction, such as marketing and product development. This has led to the relocation of production and opportunities for employment in production and a shift in the balance of power in the global economy away from firms engaged in production to firms that are well placed to attract demand. ${ }^{110}$ Firms that are engaged in production have to compete for business from brand owners and other lead firms on the basis of their ability to minimise costs and meet tight deadlines.

Lead firms face little if any direct legal responsibility for activity in their supply chains, and the burden of combatting the adverse effects of production largely falls onto the local law and regulation to which firms in supply chains are subject. There have been some soft law initiatives to encourage lead firms to exercise greater control over activity and conditions in their supply chains, in

108 Florence Palpacuer, "Bringing the Social Context Back In: Governance and Wealth Distribution in Global Commodity Chains" (2008) 37 Economy and Society 393-419.

109 The APPB Report, supra n. 56, pp. 23-26; Taplin, supra n. 10, p. 73.

110 Froud, Leaver and Williams, supra n. 13; Philip Zerrillo and Gregory Metz Thomas, "Developing Brands and Emerging Markets: An Empirical Application" (2007) 3 Place Branding and Public Diplomacy 86-99; Weil, The Fissured Workplace, supra n. 13. 
particular through the United Nations' Guiding Principles on Business and Human Rights. ${ }^{111}$ These initiatives may help to establish a platform of minimum standards for lead firms. However, it has been argued that these firms are in any event subject to commercial pressure to ensure that the risk of adverse effects occurring in their supply chains are minimised through their ownership of their brands. The argument is that brands function as "transmission mechanisms" that establish commercial accountability for supply chains as well as for branded products. ${ }^{112}$ Moreover, the character of consumerist demand may increase this pressure. This leads on to the third issue, which concerns the argument that brands can help to mitigate the social costs of consumerism through establishing commercial accountability for this that puts pressure on their owners to minimise these.

A brand's exclusivity to one firm means that it provides a means of linking specific products on the market to a specific commercial provenance. This is the basis of the commercial accountability for branded products that branding establishes. This accountability applies especially to the track record of the branded products in terms of their quality and other matters of potential interest or concern to consumers. Brands, and the trade marks that signify them, are therefore said to guarantee the quality of branded products, though the force behind it is commercial rather than legal in nature. ${ }^{113}$ However, the commercial accountability can extend, at least in principle, to cover details about the firms

111 The United Nations' Guiding Principles on Business and Human Rights (2011): see Lorraine Talbot, Great Debates in Company Law (London: Palgrave, 2014) pp. 108-137. These principles emphasise the importance of business actors exercising human rights "due diligence" to ensure that human rights are respected in their supply chains. On these initiatives generally, see also Simon Baughen, Human Rights and Corporate Wrongs: Closing the Governance Gap (Cheltenham: Edward Elgar, 2015) pp. 212-250.

112 Steve Hilton, "The Social Value of Brands" in Rita Clifton and John Simmons (eds) Brands and Branding (London: The Economist in association with Profile Books, London, 2003) 47-64, p. 55 .

113 Scandecor Development v Scandecor Marketing [2001] ETMR 800 [19]. 
involved in producing and marketing the branded products, including the social costs of production. This means that consumers should have the opportunity to favour good standards in this respect and to penalise bad standards. This opportunity underpins the argument that branding operates as a transmission mechanism that puts pressure on brand owners to ensure good standards in their supply chains. Moreover, where a brand's power to attract demand rests on the emotional appeal of its overall image, this can increase the impact of any bad publicity and thereby increase the pressure on its owner to avoid this possibility. ${ }^{114}$

However, the argument depends on a series of assumptions and these are all questionable. There is good reason to suppose that any pressure that brands may transmit back onto their owners to minimise the social costs of consumerism is much weaker than the incentives that lead them to create these costs. ${ }^{115}$ Three points are worth noting on this. One is the difficulty for consumers of acquiring or receiving clear information about social costs in supply chains. Apart from any information that the brand owner decides to convey, this largely depends on the media publicising incidents or examples of shortcomings, as with the Rana Plaza disaster. ${ }^{116}$ There is a lack of specific, objective and generally recognised standards that can be used to evaluate conditions in supply chains and other matters relating to social costs and that can help to provide reliable and meaningful information to consumers. ${ }^{117}$ This is exacerbated by the range of external organisations that provide this information, which include ones set up

\footnotetext{
114 Klein and Leffler, supra n. 68, pp. 629-633.

115 Margaret Chon, "Slow Logo: Brand Citizenship in Global Value Networks" (2014) 47 UC Davis Law Review 935-968; Margaret Chon, "Trademark Goodwill as a Public Good: Brands and Innovations in Corporate Social Responsibility" (2017) 21 Lewis \& Clark Law Review 277316.

116 Supran. 106.

117 Chon, "Trademark Goodwill as a Public Good", supra n. 115, p. 297.
} 
by brand owners, as well as independent campaigners and non-governmental organisations. This increases the scope for brand owners to provide information that is deficient or self-serving. ${ }^{118}$ It has been argued that consumers face a dual problem of lacking meaningful information and "informational clutter". ${ }^{119}$

The second point is that the transmission mechanism depends on how consumers respond in practice to information about the social costs of branded products. They are likely to weigh this information against other factors that drive their decision-making, including other matters on which they may look to a brand for reassurance. Evidence suggests that consumers in general do not reward brands sufficiently for minimising social costs; ${ }^{120}$ and that incidents of bad publicity have little if any effect on their decision-making. ${ }^{121}$ The third point is that the pressure that the transmission mechanism transmits ultimately depends on brand owners' assessment of the overall balance of costs and benefits to them from minimising social costs and, as indicated above, would have to be sufficient to outweigh the incentives that consumerism provides them. Nevertheless, in the context of consumerism, this pressure will be strongest where a brand's power to attract demand rests on an image that bad publicity about social costs would damage. ${ }^{122}$

118 Margaret Chon, "More and More(s): Certification in Global Value Chains" in Irene Calboli and Edward Lee (eds) Trademark Protection and Territoriality Challenges in a Global Economy (Cheltenham: Edward Elgar, 2014) 79-99, p. 85.

119 Margaret Chon, "Marks of Rectitude" (2009) 77 Fordham Law Review 2311-2351, p. 2316.

120 See, for example, Frank Jack Daniel, Serajul Quadir and Fiona Ortiz, "Bangladesh Disaster Crushes Owner's Ideal of Clothes with a Conscience" (Reuters, 16 June 2013) available at http://uk.reuters.com/article/uk-bangladesh-collapse-idUKBRE95F0I320130616 (accessed 8 December 2017).

${ }^{121}$ Noemi Sinkovics, Samia Ferdous Hoque and Rudolf Sinkovics, "Rana Plaza Collapse Aftermath: Are CSR Compliance and Auditing Pressures Effective?" (2016) 29 Accounting, Auditing and Accountability Journal 617-649.

122 See, for example, the impact on Starbucks of publicity concerning tax avoidance: "Starbucks suffers reputation slump over tax 'avoidance'" (The Week, 19 October 2012) available at 
Ensuring that firms that profit from consumerism have to bear the full social costs of the kind of production arrangements that it requires necessitates specific regulation and prescribed accountability mechanisms along with the kind of countervailing power that can be exerted by trade unions and campaigning organisations acting collectively. ${ }^{123}$ Within such a framework the commercial accountability that branding products achieves would be a useful supplement.

\section{Conclusion}

This article has considered how consumerism has transformed the nature of consumption, with consumers looking for products to do much more than satisfy specific functional needs. Consumerism has encouraged demand for products that are new, innovative and fashionable and for products with emotional impact. The article has also shown how the branding of products and the trade mark law that supports branding have enabled firms to exploit the opportunities for profit that consumerism has presented in a number of ways. Trade mark law has done this through enabling firms to establish brands as exclusive, personable and flexible identities that they can use to turn products into specific objects of demand and market them accordingly. Firms can also use their trade marks as reference points to promote their brands and to cultivate images and associations for them that may increase their emotional impact.

As well as enabling firms to establish brands to attract demand to their products, trade mark law complements this demand-side role through giving brand owners exclusive control over the provision of the necessary supply and

http://www.theweek.co.uk/business/49650/starbucks-suffers-reputation-slump-over-taxavoidance (accessed 8 December 2017).

${ }^{123}$ Palpacuer, supra n. 108, pp. 411-43; Sinkovics, Hoque and Sinkovics, supra n. 121. 
through giving them discretion as to how they organise supply. In effect, trade mark law achieves a formal separation of the activities of demand-attraction and supply-provision and has enabled firms to develop each of these activities separately according to its own economic logic. This facility has proven particularly useful in exploiting the opportunities that consumerism has presented.

Finally, this article has considered the social value of consumerism and therefore of trade mark law's role in helping to shape how firms have responded to it. The overall social benefit of consumerism is far from clear and it has significant social costs. The social costs along with the questionable social value of consumerism add weight to the criticism of some of the developments in trade mark law that have enabled and encouraged it, especially the extensive control that owners enjoy over the presence of their trade marks in the minds of consumers and over their referential use. Brands have the potential to mitigate some of the social costs of consumerism through the provision of salient targets for publicity, but this potential is far from sufficient without more and will need underpinning with regulation, systems of accountability and other sources of countervailing pressure to be effective in practice. 